\title{
PERGESERAN PEMAKAIAN TINGKAT TUTUR (BASE ALUS) BAHASA SASAK DI LOMBOK
}

\author{
Sudirman Wilian ${ }^{1)}$, Baiq Nurul Husaini ${ }^{2{ }^{2}}$ \\ Universitas Mataram \\ sudirman_wilian@unram.ac.id ${ }^{1)}$, karihanbiqyu@gmail.com ${ }^{2)}$
}

\begin{abstract}
This study focuses on the decreasing use of base Sasak Alus (honorific Sasak language) among the youths in Lombok. Based on the quantitative and qualitative data gained through survey, interview and observation on the younger generation in ten sub-districts of three regencies and cities of Lombok, it was found that the average mastery of the Sasak honorific vocabulary is far from adequate. Their competence in using the Sasak speech level is also poor. A number of factors may have triggered the decreasing use of the honorific Sasak variety. First is the inadequate transfer of Base Alus from parents and older family members to the children in the home domain. Second, Base Alus is rarely used outside home, except in government offices or in very formal situations such as feast or religious gathering. Third is the encroachment of the use bahasa Indonesia in almost every domain of language use. The fourth is the change of value in the marriage system for 'noblemen', which results in the loose system of the use of Base Alus. Next, dialect varieties of Sasak are quite numerous, and there is no support from the government so as to encourage Sasak as the local content material at schools.
\end{abstract}

Key words: speech level, language use, language shift, honorific language

\begin{abstract}
Abstrak
Penelitian ini berfokus pada pergeseran pemakaian Base Sasak Alus di kalangan generasi muda Sasak di Lombok. Berdasarkan data kuantitatif dan kualitatif yang diperoleh melalui survei, wawancara, dan observasi di sepuluh kecamatan di tiga kabupaten dan kota di Lombok, ditemukan bahwa rata-rata penguasaan generasi muda Sasak terhadap kosa kata Base Sasak Alus tergolong sangat kurang memadai, begitu pula kompetensi penggunaan tingkat tutur mereka sangat rendah. Ada beberapa faktor yang ditengarai menjadi penyebabnya. Yang pertama adalah kurang memadainya pengalihan Base Alus dari orang tua dan anggota keluarga yang lebih tua kepada anakanak dalam lingkungan keluarga. Kedua, Base Alus sangat jarang dipakai di lingkungan luar rumah. Ketiga, pemakaian bahasa Indonesia dalam hampir semua domain. Keempat, adanya perubahan nilai dalam sistem perkawinan keluarga bangsawan Sasak yang berimbas pada longgarnya tatakrama pemakaian Base Alus itu sendiri. Berikutnya, adanya variasi dialek dalam bahasa Sasak yang cukup beragam, dan tidak adanya dukungan pemerintah pada pembelajaran bahasa Sasak sebagai muatan lokal.
\end{abstract}

Kata kunci: tingkat tutur, pemakaian bahasa, pergeseran (variasi) bahasa, Base Alus

\section{PENDAHULUAN}

Salah satu aspek kebahasaan yang sering menjadi sorotan orang tua, tokoh masyarakat, dan para guru sejak beberapa tahun terakhir ini di Lombok adalah semakin berkurangnya kepedulian generasi muda dalam menggunakan 'tatakrama' tingkat tutur berbahasa sehari-hari baik antara orang tua dan anak di dalam rumah, antara anak dan famili lainnya maupun antara guru/orang 
dewasa dan murid di sekolah serta antara generasi muda lainnya dan para orang tua/dewasa pada umumnya. Alih-alih menggunakan 'bahasa alus', banyak remaja dan generasi muda justru dalam interaksinya dengan orangtua dan keluarga merespon dalam bahasa lndonesia jika diajak berbicara dalam bahasa daerah (Sasak). Yang menjadi kekhawatiran banyak pihak adalah jika kesinambungan pengalihan pemakaian variasi bahasa seperti ini tidak lagi diajarkan sejak dini maka besar kemungkinan, dalam beberapa generasi, masyarakat tidak akan lagi mengenal 'bahasa alus' yang merupakan kekayaan budaya bangsa. Dengan kata lain, jika kosa kata 'bahasa alus' dalam bahasa daerah itu tidak lagi dipakai, dapat dipastikan akan lenyap pula bagian dari budaya-budaya daerah yang merupakan pembentuk kebudayaan nasional Indonesia karena pada dasarnya pada bahasa dengan kosa kata halus itulah bertumpu nilai-nilai inti dari kebudayaan, termasuk pula di dalamnya budaya sopan santun. Tingkat tutur itu sendiri mengacu pada suatu sistem kode penyampaian rasa kesopanan yang di dalamnya terdapat unsur kosa kata tertentu, aturan sintaksis tertentu, aturan morfologis dan fonologis tertentu pula (Soepomo, dkk: 1972). Artikel ini akan memaparkan hasil survei dan pengamatan mengenai sejauh mana pergeseran pemakaian bahasa Sasak Alus (untuk selanjutnya BSsA) di kalangan generasi muda di Lombok telah terjadi. Selain itu, ingin pula diketahui faktor-faktor apa yang menyebabkan ketidakmampuan berbahasa alus bahasa Sasak pada generasi muda saat ini.

\section{ANALISIS TINGKAT TUTUR DALAM BERBAGAI BAHASA}

Penelitian mengenai sistem tingkat tutur dalam berbagai bahasa telah banyak dilakukan oleh para peneliti bahasa, khususnya sosiolinguis. Soepomo $(1968,1979)$, misalnya, meneliti tentang sistem tingkat tutur dalam bahasa Jawa. Ia membagi tingkat tutur dalam bahasa Jawa menjadi krama, madya, dan ngoko. Masing-masing tingkat tutur dibagi lagi menjadi tiga seperti tampak dalam tabel di bawah ini, sebagaimana dikutip dalam Rahardi (2001:58):

Tabel 1. Tingkat tutur dalam bahasa Jawa

\begin{tabular}{|c|c|}
\hline \multirow{2}{*}{ Krama } & $\begin{array}{c}\text { Muda Krama } \\
\text { Kramantara } \\
\text { Wreda Krama }\end{array}$ \\
\hline \multirow{2}{*}{ Madya } & Madya Krama \\
& Madyantara \\
& Ngoko \\
\hline \multirow{2}{*}{ Ngoko } & Basa Antya \\
& Antya Basa \\
& Ngoko Lugu \\
\hline
\end{tabular}

Menurut Soepomo (1979), tingkat tutur bahasa Jawa itu sebenarnya hanya dibagi dua, yaitu tingkat Ngoko dan Basa. Tetapi tingkat Ngoko ini dapat berbentuk macam-macam, ada bentuk yang dianggap halus dan ada pula yang dianggap biasa. Semakin banyak kata-kata Krama, Krama Inggil atau Krama Andap dalam suatu ujaran maka semakin haluslah tuturannya.

Kemudian Martin (dalam Hymes, 1964:407-413) membandingkan tingkat tutur bahasa Korea dengan bahasa Jepang. Dikemukakan bahwa kalimat-kalimat dalam bahasa Korea dan Jepang dianggap sudah lengkap hanya dengan sebuah predikat saja, tanpa adanya subjek. Akan tetapi, sebelumnya penutur bahasa Korea dan Jepang terlebih dahulu harus memilih tingkat tuturnya, yang ditentukan berdasarkan dua poros perbedaan (axes of distinction), yaitu poros pengacuan axis of reference dan poros penyebutan (penyapaan) axis of address. Pada axis of 
address dalam bahasa Jepang, tingkat tutur dibagi dalam bentuk plain (biasa), polite (sopan) dan deferential (hormat), sedangkan dalam bahasa Korea, pemilihan axis of address terlebih dahulu harus diketahui apakah seseorang masuk dalam ingroup atau outgroup. Apabila lawan bicara masuk pada kelompok pertama maka tingkat tutur harus dipilih: plain (biasa), intimate (intim), atau familiar (akrab), dan apabila masuk pada kelompok kedua harus dipilih antara bentukbentuk polite (sopan), authoritative (kewenangan) atau deferential (hormat). Masing-masing bentuk ditandai oleh sufiks tertentu pada kata kerjanya. Singkatnya, pemilihan bentuk plain, polite, dan deferential baik dalam bahasa Jepang maupun Korea bergantung pada sikap penutur terhadap lawan bicaranya atau orang yang dibicarakan, sedangkan pilihan bentuk tutur humble (merendah), neutral (netral) atau exalted (agung/mulia) bergantung terutama pada sikap pembicara pada subjek pembicaraan (subject of the expression). Martin menyimpulkan bahwa sistem tingkat tutur dalam dua bahasa serumpun ini begitu kompleks yang ditentukan oleh perbedaan usia, jenis kelamin, kedudukan sosial, keanggotaan dalam kelompok. Sejalan dengan hal ini, Holmes (1992:271) juga berpendapat bahwa pilihan atas bentuk tutur yang sesuai untuk digunakan juga tidak hanya ditentukan oleh ucapan, tetapi bentukan kata dan sintaksisnya.

Dalam literatur lain ditemukan pula bahwa tingkat tutur dalam banyak bahasa ditentukan pula oleh pemakaian bentuk sapaan (address system) bahasa bersangkutan. Misalnya, dalam bahasa Inggris penyebutan nama keluarga yang didahului sebutan gelar Tuan atau Nyonya (title with last name) atau nama pertama/panggilan akrab (nick name) dapat menunjukkan tingkat tutur sekaligus kesantunan pembicara terhadap lawan bicaranya (Brown and Ford, dalam Hymes, 1964). Begitu pula yang terjadi di Iran pasca revolusi Syah Iran bahwa sistem pemakaian pronomina untuk menunjukkan jati diri seseorang dan orang lain dalam suatu tindak tutur merupakan hal yang jelas. Dengan kata lain bentuk pronomina merupakan cara pengacuan yang paling utama (Keshavars, 1988). Secara ringkas dapat dikatakan bahwa pemakaian bentuk sapaan untuk menyatakan tingkat tutur dalam suatu bahasa mengacu pada dua pola, yaitu (1) self-lowering (merendahkan diri penutur), dan (2) other raising (meninggikan mitra tutur). Gu (1990:237-257) menyebut pola ini sebagai address maxim, yang artinya, 'panggillah lawan bicara Anda dengan sebutan yang pantas'.

\section{TINGKAT TUTUR BAHASA SASAK}

Pemakaian tingkat tutur dalam suatu bahasa tentu tidak dapat dilepaskan dari masalah ragam bahasa dan kesantunan. Pada umumnya, bagi masyarakat kebanyakan di Lombok dikenal ada dua bentuk (ragam) bahasa dalam komunikasi sehari-hari, yaitu bahasa Sasak biase/jamaq dan bahasa Sasak alus. Pembagian ini didasarkan pada stratifikasi sosial masyarakat Sasak secara umum, yaitu sebagai bangsawan Perwangse atau Menak dan bukan bangsawan Non-Menak atau Jajarkarang. Namun, ada juga yang menyebutkan tiga tingkatan, seperti yang dilaporkan oleh Anhari (2009:29), bahwa di Desa Durian kecamatan Janapria (Lombok Tengah), berdasarkan pelapisan sosial masyarakatnya tingkat tutur masyarakatnya ada tiga, yaitu bahasa utama (bahasa alus), bahasa madya (bahasa sedang), dan bahasa nista (bahasa kasar). Hafifah (2009: 27-37) juga menyebutkan bahwa di Desa Tanak Awu (kec. Pujut, Lombok Tengah) dikenal adanya tiga tingkatan tersebut. Pembagian itu juga didasarkan atas tiga lapisan sosial masyarakatnya, yaitu golongan bangsawan yang dikenal dengan sebutan Menak (Perwangse), golongan masyarakat menengah yang disebut Perbape, dan golongan masyarakat biasa yang dikenal dengan masyarakat Jajarkarang. Karena itu pula, bentuk tingkat tuturnya didasarkan 
atas tiga tingkatan itu. Yang pertama disebut bentuk kaji-meran, yang kedua tiang-inggih, dan yang ketiga disebut aoq-ape. Yang pertama dan kedua merupakan padanan dari saya-ya, dan yang ketiga merupakan padanan ya-apa.

Faktor-faktor yang menyebabkan pemilihan terhadap salah satu dari kedua atau ketiga bentuk tingkat tutur tersebut, seperti juga dalam bahasa-bahasa lain, adalah usia, status sosial (termasuk faktor keturunan), pendidikan, tingkat keakraban, situasi percakapan, jenis percakapan (formal/informal). Pada banyak bahasa, umumnya digunakan bentuk pronomina yang berbeda-beda untuk menunjukkan perbedaan rasa hormat. Di samping itu juga dipakai kata kerja, kata benda, dan kata sifat yang berbeda untuk menyebut O1 (orang ke-1) dan O2 (orang ke-2) dalam tingkat tuturnya. Dalam bahasa Sasak pemakaian bentuk halus kata kerja, kata benda dan kata sifat juga berlaku namun jumlah kosa kata itu sangat terbatas dan umumnya dikenal oleh 'priyayi' Sasak serta kaum 'menak'. Lazimnya lagi, untuk menunjukkan perbedaan rasa hormat bagi kebanyakan rakyat biasa hanya mengenal bentuk bahasa alus melalui penggunaan bentuk-bentuk pronomina dan beberapa kata tugas semacam partikel silaq atau ngiring untuk 'silakan' atau 'mari' dan kata penunjuk niki atau nike untuk 'ini/itu'. Tabel 2 di bawah ini menampilkan bentuk-bentuk pronomina dalam bahasa Sasak.

Tabel 2. Bentuk Pronomina Bahasa Sasak (Wilian, 2006)

\begin{tabular}{|c|c|c|c|c|}
\hline & Orang ke-1 & \multicolumn{2}{|c|}{ Orang ke-2 } & Orang ke-3 \\
\hline Tunggal pria (biasa) & \multirow{2}{*}{$a k u$} & Ante & \multirow{2}{*}{ Кати } & \multirow{2}{*}{ ie/nie } \\
\hline Tunggal wanita (biasa) & & Кати & & \\
\hline Tunggal (alus) sedang & tiang & \multicolumn{2}{|c|}{ Side } & \\
\hline $\begin{array}{l}\text { Tunggal (sangat alus/ } \\
\text { high honorific) }\end{array}$ & kaji & \multicolumn{2}{|c|}{$\begin{array}{c}\text { pelinggih/plungguh } \\
\text { dekaji }\end{array}$} & deside \\
\hline Jamak inklusif & ite & & & \\
\hline Jamak eksklusif & kami & & & \\
\hline
\end{tabular}

Dari tabel di atas terlihat bahwa bentuk pronomina orang pertama ada tiga: aku, tiang dan kaji. Bentuk pronomina $\mathrm{O} 2$ ada lima: ante, kamu, side, plinggih/plungguh dan deside. Namun, bentuk kaji (saya) dan dekaji (anda) sudah sangat jarang sekali dipakai, atau bahkan sama sekali tidak dipakai lagi kecuali pada acara kepembayunan ${ }^{l}$ pada saat acara adat sorong $\operatorname{serah}^{2}$ dalam prosesi perkawinan adat Sasak di Lombok. Bagi sebagian besar dialek-dialek Sasak di Lombok, terutama dialek Selaparang atau dialek 'Ngeno-ngene' (itu-ini), bentuk pronomina orang kedua tunggal dibedakan antara $\mathrm{O} 2$ laki 'ante' dan $\mathrm{O} 2$ wanita ' $k a m u$ ' untuk bahasa biasa, sedangkan untuk menyatakan hormat kepada orang tua, orang yang dituakan atau orang yang belum dikenal umumnya digunakan kata 'side' (tapi bukan bentuk netral) atau kadang-kadang 'plinggih' atau 'plungguh' (untuk yang lebih dihormati atau lebih menghormat) baik laki maupun perempuan seperti pada tuturan Uaq (paman) terhadap Naken (keponakan) dalam dialek Selaparang atau Pejanggik berikut (dalam Wilian, 2006):

(1) U: Mek* lalo jok mbe atau mbe jaq melaiq (meq laiq)?

'Kamu (laki) mau ke mana?'

N: Ku lalo jok balen papuq Ramiah atau Jaq kulalo jok balen papuq Ramiah. 'Saya mau ke rumah nenek Ramiah.'

* Catatan: Kata meq/bi = bentuk lain dari anta/kamu dalam kalimat tanya dan menyangkal dalam bahasa Sasak biasa dialek Ngeno-Ngene. 
(2) N: Da lalo jok mbe atau Mbe jaq de laiq?

U: Ku lalo jok balen papuq Ramiah atau Jaq kulalo jok balen papuk Ramiah.

(3) N: Pelinggih lalo jok mbe? atau Mbe plinggih lai?

M: Tiang lalo jok balen papuk Ramiah.

(4) N: Mbe plinggih lumbar? atau Plinggih lumbar jok mbe?

'kemana anda hendak pergi?' (lit.)

K: Tiang lalo jok pegedengan papuq Ramiah.

Berdasarkan contoh (1) s.d (4) di atas, dapat dikatakan bahwa bahasa Sasak mengenal adanya tingkat tutur, yang dalam contoh $\mathrm{O} 1$ dan $\mathrm{O} 2$ di atas menggunakan bentuk kata pronomina, kata benda, kata kerja, dan kata tugas yang berbeda untuk situasi, konteks dan interlokutor yang berbeda pula. Sebagaimana pada bahasa Jawa, Bali, Madura dan Sunda, tingkat tutur dalam bahasa Sasak dapat pula dinyatakan dengan sejumlah kosa kata halus pada kata kerja, kata benda, kata sifat, dan kata tugas, seperti pada contoh (4). Namun jumlah semua kosa kata halus ini sangat terbatas jika dibandingkan dengan kosa kata halus bahasa Jawa. Di samping itu, pemakaiannya di kalangan masyarakat biasa pun sangat jarang terdengar, kalaupun dipakai masih terbatas hanya beberapa kata saja. Hal ini sangat berbeda dengan tingkat tutur dalam bahasa Jawa di mana hampir semua lapisan masyarakatnya, berdasarkan pengalaman dan pengamatan penulis, mengetahui dan menggunakan semua tingkat tutur itu.

\section{KAJIAN TERDAHULU TENTANG PERGESERAN TINGKAT TUTUR}

Sesungguhnya perhatian terhadap fenomena pergeseran tingkat tutur bahasa sudah lama menjadi perbincangan para ahli bahasa di Indonesia, khususnya terhadap 'unggah-ungguh ing basa' Bahasa Jawa. Sudaryanto (1987:1-3), misalnya, memaparkan salah satu alasan ditulisnya buku Unggah-ungguh ing Basa dalam Bahasa Jawa tahun 1958 oleh R. Kartoamijoyo (yang kemudian diterbitkan tahun 1962) adalah karena banyaknya pemuda Jawa pada waktu itu yang tidak mempedulikan lagi bahasa Jawa. Alasannya, mereka takut kalau salah menempatkan penggunaan tingkat tuturnya yang bisa berakibat dicap tidak kenal sopan santun. Sudaryanto menyatakan bahwa kegoyahan mengenai tata tertib pemakaian tingkat tutur bahasa Jawa Krama itu sudah mengindikasikan tergerogotinya bahasa Jawa secara serius sejak tahun 1950-an. Disebutkan pula bahwa sudah sejak awal abad ke-20, sebagaimana dikutip dari keterangan Profesor Hoesein Djajadiningrat oleh Prof. E.M. Uhlenbeck tahun 1970, "banyak di antara pemakai bahasa Jawa, khususnya mereka yang termasuk golongan terdidik, merasa bahwa mereka tidak dapat lagi mengandalkan pada kemampuan mereka untuk memakai ragam bahasa yang sesuai dan untuk menyusun bentuk hormat yang dikehendaki dalam setiap situasi pertuturan" (ibid).

Tampaknya, apa yang pernah dikemukakan oleh para pengamat bahasa mulai awal abad ke-20, kemudian dasawarsa 50-an, kemudian dasawarsa 80-an sampai dekade 2000-an atau awal abad ke-21 mengenai keterdesakan tingkat tutur, khususnya Bahasa Jawa, telah menunjukkan fenomena kebahasaan yang sama dari waktu ke waktu. Dalam arti bahwa apa yang sebenarnya dikhawatirkan para ahli bahasa pada awal, pertengahan, dan sampai pada akhir abad ke-20 yang lampau belum sampai melenyapkan ragam bahasa yang menyatakan kesantunan tersebut, walaupun sampai pada hasil penelitian yang sama beberapa waktu yang lalu juga telah dilakukan terhadap bahasa Jawa oleh Subroto, dkk. (2007). Hasil kajian itu menyimpulkan bahwa tingkat tutur bahasa Jawa sedang mengalami keterancaman karena 
kemampuan generasi muda Jawa yang benar dan tepat dalam berbahasa Jawa ragam Krama dan Krama Inggil tergolong kurang. Subroto memaparkan bahwa pemahaman generasi muda terhadap penggunaan kosa kata Ngoko, Krama, dan Krama Inggil dengan benar dan tepat tergolong kurang. Para peneliti menyimpulkan bahwa bahasa Jawa, yang jumlah penuturnya sangat besar sekalipun, tidak luput dari keterancaman pergeseran. Demikian pula hasil penelitian yang dilakukan oleh Sariono (2002) terhadap tingkat tutur bahasa Jawa di Diponggo, sebuah desa di pesisir utara Pulau Bawean, Kabupaten Gresik - Jawa Timur. Peneliti ini juga menyimpulkan bahwa ragam bahasa halus (tingkat tutur) bahasa Jawa di Diponggo (BJD) itu terancam punah. Hal itu karena tingkat pemertahanan tingkat tutur bahasa Jawa di sana (dengan penduduk pada tahun 1993 berjumlah 1.081 jiwa) berbeda-beda antar kelompok sosial masyarakat. Menurutnya, semakin tua usia dan semakin tinggi status sosial penutur, semakin tinggi pula tingkat pemertahanannya. Sebaliknya, semakin muda usia dan semakin rendah status sosial penutur, semakin rendah pula tingkat pemertahanannya. Sariono menyimpulkan bahwa anak-anak berusia 15 tahun atau kurang telah tidak memiliki pemertahanan tingkat tutur BJD. Faktor penyebabnya berpangkal pada kebiasaan sebagian besar masyarakatnya yang suka merantau. Diperkirakan dalam waktu satu atau dua generasi lagi, tingkat tutur dalam BJD akan punah.

\section{KONSEP TEORETIS TENTANG PERGESERAN DAN PEMERTAHANAN BAHASA/RAGAM BAHASA}

Secara teoretis kajian tentang pergeseran dan pemertahanan ragam bahasa termasuk tingkat tutur tentu tidak dapat dilepaskan dari kajian pergeseran dan pemertahanan bahasa. Hal itu karena pada dasarnya pergeseran tingkat tutur (ragam bahasa) juga sekaligus menyangkut pergeseran bahasa atau ragam bahasa itu sendiri, yang substansinya berkenaan dengan pemakaian dan pilihan bahasa, ranah pakai bahasa, diglosia, dan sikap bahasa. Istilah diglosia, yang secara luas dipakai dalam sosiolinguistik dan sosiologi bahasa ini, mengacu pada situasi kebahasaan di mana setiap bahasa atau ragam bahasa, baik pada masyarakat ekabahasa (monolingual), dwibahasa (bilingual), atau anekabahasa (multilingual), mempunyai peran dan fungsi masing-masing yang berbeda-beda sesuai peruntukannya (Ferguson, 1959). Pembagian atau pemisahan fungsi itu biasanya dikaitkan dengan apa yang diistilahkan dengan ragam bahasa $\mathrm{T}$ (Tinggi) dan ragam bahasa $\mathrm{R}$ (Rendah). Ragam bahasa $\mathrm{T}$ dikaitkan dengan bahasa atau ragam bahasa yang dihargai dan diakui dalam masyarakat mempunyai nilai tinggi, sedangkan ragam bahasa $\mathrm{R}$ dihargai mempunyai nilai yang lebih rendah.

Ranah-ranah pemakaian bahasa informal seperti keluarga, tetangga, dan kekariban dianggap merupakan ranah di mana fungsi bahasa $\mathrm{R}$ digunakan, sedangkan ranah agama, pendidikan, pemerintahan, dan lingkungan kerja yang dianggap ranah pemakaian bahasa formal termasuk wilayah ranah bahasa T. Dalam masyarakat yang diglosik setiap bahasa mempunyai fungsi sendiri-sendiri yang digunakan oleh anggota masyarakatnya itu untuk menyatakan kehendaknya menurut norma sosial dalam masyarakat bahasa bersangkutan. Pemakaian tiaptiap bahasa atau ragam bahasa itu ditentukan oleh perilaku, sikap, dan nilai-nilai yang ada pada masyarakat itu menyangkut setiap bahasa atau ragam bahasa yang digunakan. Adanya perbedaan sikap dan pandangan terhadap tiap-tiap bahasa itu disebabkan oleh kenyataan bahwa di dalam masyarakat ekabahasa atau anekabahasa setiap bahasa atau ragam bahasa dianggap mempunyai 'keterbatasan' (dalam arti mempunyai fungsi) sendiri-sendiri. Tidak semua bahasa 
atau ragam bahasa dapat mewakili setiap situasi pemakaian bahasa. Akan tetapi, pemakaian tiap-tiap bahasa itu pun acap kali masih ditentukan lagi oleh 'peraturan' siapa berbicara kepada siapa (role relationship), di mana, untuk tujuan apa, tentang apa, dan lain lain. 'Peraturan' pemakaian bahasa dalam komunikasi ditentukan pula oleh faktor-faktor yang sifatnya nonlinguistik. Dalam sosiolinguistik faktor-faktor itu dapat disebut sebagai komponen tutur (components of speech). Yang perlu diwaspadai dalam pemakaian dan pilihan bahasa itu adalah bahwa jika ranah-ranah pemakaian bahasa yang tadinya diwakili oleh ragam bahasa $\mathrm{R}$ sudah dimasuki atau digantikan oleh ragam bahasa $\mathrm{T}$ (diglossia leakage) maka patut diwaspadai akan dimulai terjadinya pergeseran bahasa.

Pertanyaan yang sering muncul dalam masyarakat dwibahasa atau anekabahasa adalah faktor-faktor apakah yang dapat mempengaruhi penggunaan bahasa selain bahasa ibu itu? Menurut Platt (1977), dimensi identitas sosial merupakan faktor yang dapat mempengaruhi penggunaan bahasa di dalam masyarakat anekabahasa. Dimensi itu mencakup kesukuan, umur, jenis kelamin, tingkat dan sarana pendidikan, serta latar belakang sosial-ekonomi. Kemudian ia menggabungkan semua faktor tersebut dengan faktor ranah, penutur, mitra tutur dan hubungan antara kedua faktor yang disebutkan terakhir. Bukti-bukti dari masyarakat urban di Afrika menunjukkan pula bahwa pola pilihan bahasa itu berbeda-beda menurut latar belakang sosial penutur dan jenis interaksi yang melibatkan mereka. Sebagian besar masyarakat urban di Kenya, misalnya, menggunakan bahasa ibu mereka di rumah atau dengan anggota masyarakat lainnya yang berasal dari satu kelompok etnis di lingkungan mereka. Bahasa ibu penting digunakan karena merupakan alat untuk mempertahankan identitas etnis mereka di samping sebagai cara untuk memperoleh keuntungan materi tertentu, misalnya, memperoleh bantuan dari anggota kelompok mereka itu untuk mendapatkan pekerjaan (Mesthrie \& Leap, 2000:154-155).

Salah satu aspek yang juga berkaitan sangat erat dengan kajian masalah pemertahanan dan pergeseran bahasa dalam masyarakat dwibahasa atau anekabahasa adalah sikap bahasa. Kajian terhadap sikap bahasa yang bertitik tolak terutama dari teori-teori psikologi sosial telah banyak dilakukan orang. Sikap itu sendiri menurut Myers (dalam Sarwono, 2002:232) “ ... is a favourable or unfavourable evaluative reaction toward something or someone, exhibited in one's belief, feelings or intended behaviour." Sikap merupakan reaksi seseorang baik yang menyenangkan atau tidak menyenangkan terhadap sesuatu atau seseorang, yang dinyatakan melalui perasaannya, kepercayaannya, atau perilakunya. Ciri utama sikap adalah: (1) mempunyai objek tertentu (orang, perilaku, konsep, situasi, benda, dan sebagainya), dan (2) mengandung penilaian (setuju-tidak setuju, suka-tidak suka). Sikap adalah sesuatu yang dipelajari (bukan bawaan). Oleh karena itu, ia dapat dibentuk dan dikembangkan sepanjang keterlibatan orang itu terhadap objeknya dan apabila terdapat keadaan-keadaan dan syarat-syarat tertentu yang memungkinkannya. Sikap itu sendiri dapat dibagi menjadi tiga komponen atau domain, yaitu (1) domain kognitif, (2) domain afektif, dan (3) domain konatif. Karena ketiga domain itu saling terkait, menurut Sarwono (2002:234), timbul teori bahwa jika kita dapat mengetahui kognisi dan perasaan seseorang terhadap suatu objek sikap tertentu, kita akan tahu pula kecenderungan pelakunya.

Berdasarkan teori-teori psikologi sosial mengenai sikap ini, para peneliti di bidang sosiolinguistik kemudian mengembangkan metode dan alat-alat evaluasi untuk mengetahui sikap seseorang atau sekelompok orang terhadap suatu bahasa tertentu, yang kemudian melahirkan adanya sikap bahasa. Menurut Anderson, sebagaimana dituangkan di dalam Suhardi (1996:35), sikap bahasa adalah "tata kepercayaan yang berhubungan dengan bahasa yang secara 
relatif berlangsung lama, mengenai suatu objek bahasa yang memberi kecenderungan kepada seseorang (yang memiliki sikap bahasa itu) untuk bertindak dengan cara tertentu yang disukainya." Menurut Garvin dan Mathiot (1972:371-373) sikap bahasa dapat dibagi tiga, yaitu kesetiaan bahasa (language loyalty), kebanggaan bahasa (language pride), dan kesadaran akan norma bahasa (awareness of the norm). Yang pertama berkenaan dengan sikap setia masyarakat untuk mempertahankan bahasanya, dan apabila perlu mencegah adanya pengaruh bahasa lain. Yang kedua merupakan sikap bangga masyarakat untuk mengembangkan dan menggunakan bahasanya sebagai lambang identitas dan kesatuan kelompok masyarakatnya. Dan yang terakhir menyangkut kesadaran menggunakan bahasa dengan cermat dan santun. Ketiga jenis sikap bahasa ini merupakan ciri sikap positif terhadap bahasa, yang apabila dapat ditumbuhkembangkan di dalam masyarakat tutur, hal itu akan berdampak pada kebertahanan bahasa masyarakat itu. Sebaliknya, apabila ketiganya tidak dimiliki oleh masyarakat tutur suatau bahasa atau masyarakat itu bersikap negatif terhadap bahasanya maka hal itu lambat-laun dapat mengakibatkan bahasa itu menjadi terbengkalai di dalam wilayah pakainya, kemudian meredup, dan akhirnya sirna dari buminya sendiri.

\section{METODE PENELITIAN}

Populasi penelitian ini adalah penduduk kelompok etnis Sasak di Pulau Lombok yang berdomisili di sepuluh kecamatan di Kabupaten Lombok Barat, Lombok Tengah dan Lombok Timur serta kota Mataram dengan lima kelompok rentang usia mulai 11 sampai 35 tahun. Saat ini, menurut data kependudukan tahun 2017, penduduk pulau ini berjumlah 3.311.044 jiwa, dengan urutan jumlah penduduk terbesar berada di Lombok Timur, diikuti Lombok Tengah, dan Lombok Barat. Untuk pengumpulan data digunakan ancangan model penelitian kualitatif dengan metode survei, ethnografi, dan uji kompetensi. Untuk menjaring data penelitian survei, penentuan pengambilan sampel dilakukan dengan teknik pemercontohan acak purposif berkuota (quota purposive random sampling) dan teknik pemercontohan berlapis (Townroe dan Yates, 1995:338 dalam Gunarwan, 2001:77). Teknik purposif berkuota digunakan untuk menetapkan jumlah anggota sampel per lokasi (per kecamatan dan desa/kelurahan) per kelompok usia dengan interval lima tahun. Kemudian, teknik berlapis dimaksudkan untuk menetapkan anggota sampel sesuai dengan kuota yang ada yang dikaitkan dengan karakteristik atau kategori percontoh (sampel frame) yang diinginkan (Milroy, 1987: 19 dalam Gunarwan, 2001). Besarnya jumlah subjek percontoh dihitung berdasarkan kuota yang ditentukan sebanyak 15 orang (percontoh) per kategori atau per sel variabel dengan memperhatikan mobilitas sosial, latar belakang pendidikan, dan kelompok ekonomi. Jumlah keseluruhan subjek percontoh dihitung menurut jumlah sel pada setiap variabel. Ada enam variabel yang diperkirakan berpengaruh terhadap pemakaian bahasa halus dalam penelitian ini, yaitu usia, pendidikan, pekerjaan, jenis kelamin, dan ranah pemakaian bahasa (lihat Tabel 3).

Berdasarkan banyaknya sel-sel pada setiap variabel itu kemudian dihitung jumlah keseluruhannya dan diperoleh $6+2+5+5+6=24$. Apabila setiap sel itu diisi 16 percontoh, maka 15 x $24=360$ percontoh. Dengan demikian per contoh yang diperlukan dalam penelitian ini sebanyak 360. Sankoff dalam Milroy (1987) mengatakan bahwa percontoh untuk penelitian bahasa tidak sama dengan penelitian non-bahasa karena perilaku berbahasa lebih homogen dari pada perilaku sosial yang lain, misalnya perilaku membaca novel pada remaja di perkotaan. Karena itu, percontoh penelitian bahasa yang besar tidak diperlukan. Dalam penelitian bahasa 
yang penting adalah sampel itu dapat mencerminkan perilaku populasi yang diwakilinya dan sesuai dengan variabel yang akan digeneralisasikan.

Tabel 3. Nama Variabel dan Kategori

\begin{tabular}{|c|c|c|c|}
\hline No & Nama Variabel & $\begin{array}{c}\text { Jumlah } \\
\text { Sel/Kategori }\end{array}$ & Nama Kategori \\
\hline 1 & Pekerjaan & 6 & $\begin{array}{l}\text { - tidak bekerja } \\
\text { - pegawai negeri/swasta } \\
\text { - pelajar/mahasiswa } \\
\text { - petani } \\
\text { - pedagang/wiraswasta } \\
\text { - tukang, kusir, supir }\end{array}$ \\
\hline 2. & Jenis kelamin & 2 & $\begin{array}{l}\text { - laki-laki } \\
\text { - perempuan }\end{array}$ \\
\hline 3. & Umur & 5 & $\begin{array}{l}-11-15 \text { tahun } \\
-16-20 \text { tahun } \\
-21-25 \text { tahun } \\
-26-20 \text { tahun } \\
-31-35 \text { tahun }\end{array}$ \\
\hline 4. & Pendidikan & 5 & $\begin{array}{l}\text { - tidak sekolah } \\
\text { - SD/M.I } \\
\text { - SMP/M.Ts } \\
\text { - SMA/SMK/MA } \\
\text { - PT/Akademi (S1/Diploma) }\end{array}$ \\
\hline 5. & Ranah & 6 & $\begin{array}{l}\text { - kekeluargaan } \\
\text { - ketetanggaan } \\
\text { - kekariban } \\
\text { - pendidikan } \\
\text { - pemerintahan } \\
\text { - keagamaan } \\
\end{array}$ \\
\hline & Jumlah & & 24 kategori/sel \\
\hline
\end{tabular}

Untuk melihat keabsahan data kebahasaan hasil survei dilakukan trianggulasi sumber data dengan mencari sumber data dari berbagai sumber informan, terutama para tetua dan para pemerhati Unggah-Ungguh Base Sasak Alus yang mengetahui seluk beluk pemakaiannya (wawancara dan studi dokumentasi) serta trianggulasi metode pengumpulan data dengan pengamatan terlibat (participant observer). Data utama penelitian diperoleh dari jawaban responden yang diperoleh melalui instrumen kuesioner survei, yang terdiri dari tiga bagian. Bagian I menanyakan data pribadi responden yang mencakup jenis kelamin, kelompok umur, tempat lahir, pendidikan, dan pekerjaan. Bagian II berisi latar belakang kebahasaan masingmasing responden terkait dengan seberapa banyak mereka mengetahui ikhwal bahasa alus dan bagaimana kebiasaan penggunaan bahasa halus mereka di rumah dengan orangtua atau anak, dengan orang yang dituakan (dihargai), seberapa sering mereka menggunakannya dan sejak kapan, dan lain-lain (lihat lampiran). Bagian ini berisi 11 pertanyaan yang diajukan kepada responden untuk menjaring data mengenai perilaku dan sikap bahasa (language behaviour and language attitude) responden terhadap bahasa Sasak Alus. Di samping itu, beberapa pertanyaan juga diajukan untuk menjaring data tentang penggunaan bahasa dan pilihan bahasa (language use and language choice) yang menjadi khazanah kebahasaan responden dalam ranah rumah tangga. Kuesioner ini berisi daftar pertanyaan pancingan pengakuan diri (self-report) tentang 
pemakaian dan pilihan bahasa responden. Pilihan bahasa yang digunakan diberi nilai "purapura" (dummy values) $1-4$ ( 1 = (hampir) selalu, $2=$ sering, $3=$ jarang, $4=$ tidak pernah).

Bagian III dan IV berisi tes kemampuan kosa kata dan kemampuan menggunakan BSsA dalam bentuk kalimat sederhana. Tes kemampuan kosa kata berisi 25 kosa kata halus yang paling umum digunakan untuk dicarikan padanannya atau sinonimnya dalam bahasa Sasak Jamak (biasa) atau bahasa Indonesia. Sedangkan tes kemampuan menggunakan bahasa Sasak berisi 12 kalimat Bahasa Indonesia sederhana yang diminta untuk diterjemahkan ke dalam BSsA. Untuk memperoleh data kompetensi komunikatif dalam BSsA responden juga diberikan tes pemahaman kosa kata halus dan tes kemampuan dasar BSsA sederhana yang diterjemahkan dari Bahasa Indonesia ke dalam BSsA. Data kemampuan BSsA kemudian dianalisis dan dikoreksi dengan diberi skor 10 - 100. Skor pengetahuan kosa kata halus dan skor kemampuan berbahasa halus kemudian dikelompokkan menjadi lima kategori kemampuan, yaitu:

$$
\begin{array}{lll}
\text { Kategori I } & : 1-45=\text { sangat kurang } \\
\text { Kategori II } & : 46-55=\text { kurang } \\
\text { Kategori III } & : 56-69=\text { cukup } \\
\text { Kategori IV } & : 70-85=\text { baik } \\
\text { Kategori V } & : 86-100=\text { sangat baik }
\end{array}
$$

Dari 360 kuesioner survei yang disebarkan, 341 berhasil dikembalikan, namun setelah diseleksi dan diklasifikasi ada 16 kuesioner yang tidak layak untuk dianalisis, sehingga tersisa 325 kuesioner, yang terdiri dari 165 responden laki-laki $(51,7 \%)$ dan 157 responden perempuan $(48,3 \%)$.

\section{ANALISIS DATA DAN PEMBAHASAN}

Bagian ini akan membahas pola pemakaian BSsA serta penguasaan kosa kata dan kemampuan menyusun kalimat dalam BSsA oleh generasi muda di Lombok. Faktor-faktor yang diasumsikan menjadi penyebab pergeseran pemakaian BSsA juga akan dibahas.

\section{Pola Pemakaian BSsA pada Ranah Keluarga, Pendidikan/Pemerintahan, dan Situasi Tertentu}

Dalam konteks pemakaian Tingkat Tutur BSs yang dinyatakan dengan pemakaian leksikon halus (honorific words) dalam ranah-ranah kebahasaan (language domain) sebagai faktor internal pemertahanan bahasa/variasi bahasa tampak adanya keragaman pilihan jawaban diantara berbagai lapisan masyarakat yang tentu saja dapat dilihat baik dari perbedaan usia, jenis kelamin, pendidikan, pekerjaan, dan latar sosial. Berdasarkan hasil penghitungan komputer atas jawaban responden terhadap pernyataan mengenai kekerapan dan kebiasaan pemakaian BSsA di dalam keluarga diperoleh bahwa, sebagaimana terlihat dalam Tabel 4, sebanyak 51,7\% mengatakan 'pernah' menggunakan BSsA dengan orang tua atau keluarga lainnya di dalam rumah, $14,5 \%$ mengatakan 'tidak pernah', 18,8\% mengatakan 'sering', dan hanya 12,6\% mengatakan 'selalu', sisanya 2,5\% tidak mengisi. Dilihat dari data latar sosial responden patut diduga bahwa mereka yang selalu menggunakan BssA di rumah tersebut adalah berasal dari keluarga Menak, yang merupakan 9.5\% dari total responden. 
Tabel 4. Kekerapan Pemakaian BssA pada Ranah Keluarga, Sekolah/Pemerintahan, dan Situasi Tertentu

\begin{tabular}{lcccccc}
\hline & \multicolumn{5}{c}{ Ranah Pemakaian } \\
\cline { 2 - 7 } $\begin{array}{l}\text { Kekerapan } \\
\text { mengguna- } \\
\text { kan BssA }\end{array}$ & $\begin{array}{c}\text { Keluarga/ } \\
\text { famili } \\
\text { lainnya }\end{array}$ & $\%$ & $\begin{array}{c}\text { Sekolah/pemerin- } \\
\text { tah (dg guru, } \\
\text { pegawai, tata } \\
\text { usaha) }\end{array}$ & $\%$ & $\begin{array}{c}\text { Situasi tertentu/ } \\
\text { luar rumah } \\
\text { (orang yang } \\
\text { dituakan, } \\
\text { dihormati) }\end{array}$ & $\%$ \\
\hline Selalu & 41 & 12,6 & 34 & 10,5 & 81 & 24,9 \\
\hline Sering & 61 & 18,8 & 78 & 24,0 & 78 & 24,0 \\
\hline Pernah & 168 & 51,7 & 134 & 41,2 & 97 & 29,8 \\
\hline $\begin{array}{l}\text { Tidak } \\
\text { pernah }\end{array}$ & 47 & 14,5 & 42 & 12,9 & 49 & 15,1 \\
\hline $\begin{array}{l}\text { Tidak } \\
\text { mengisi }\end{array}$ & 8 & 2,5 & 37 & 11,4 & 20 & 6,2 \\
\hline Total & 325 & 100 & 325 & 100 & 325 & 100 \\
\hline
\end{tabular}

Demikian pula halnya dengan pemakaian BSsA di sekolah dan kantor, kekerapan penutur menggunakan 'hampir selalu' BSsA hampir sama besarnya dengan penggunaan BSsA di dalam keluarga, yang terpaut hanya 2,1\%, sebagaimana terlihat pada tabel di atas dan grafik pada Gambar 1 di bawah ini. Boleh jadi penutur yang 'selalu' menggunakan BSsA di kedua ranah tersebut adalah dari responden yang sama. Terlihat pula pada Tabel 4 di atas bahwa kebanyakan responden hanya 'pernah' menggunakan BSsA baik pada ranah keluarga maupun ranah pendidikan dan pemerintahan, yang secara berturut-turut persentasenya 51,7\% dan 41,2\%. Akan tetapi, pada ranah situasi tertentu jawaban responden untuk yang 'selalu', 'sering', dan 'pernah' menggunakan BSsA persentasenya tidak terlalu berbeda jauh, yakni berturut-turut $24,9 \%, 24,0 \%$, dan 29,8\%. Demikian pula dengan yang menyatakan 'tidak pernah', persentasenya juga hampir sama, yakni $14,5 \%, 12,9 \%$, dan 15,1\%.

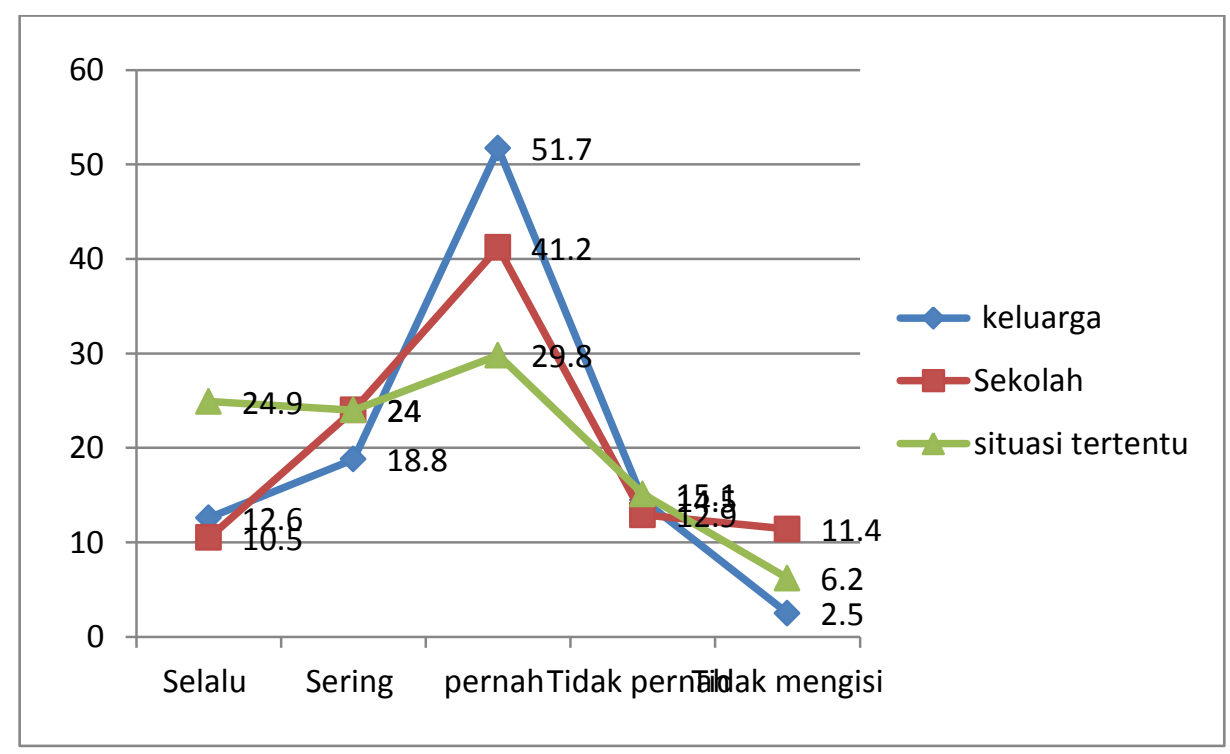

Gambar 1. Grafik persentase kekerapan pemakaian BSsA pada ranah keluarga, sekolah, dan situasi tertentu 
Berdasarkan data ini besar kemungkinan responden yang menyatakan pernah dan tidak pernah atau sering menggunakan BSsA di sekolah atau di kantor merasa lebih nyaman bila menggunakan Bahasa Indonesia daripada BSsA walaupun seringkali guru/pegawai mengajak menggunakan Babasa Sasak, sebagaimana dituturkan beberapa guru kepada peneliti ini. Dan boleh jadi pula mereka itu memang tidak bisa menggunakan BSsA karena ketidaktahuan dan tidak pernah diajarkan oleh orangtua. Data ini tampaknya mendukung apa yang ditemukan Wilian (2009:38-43) di mana pilihan bahasa masyarakat pada ranah pendidikan dan pemerintahan hampir sama, yaitu 3,59 dan 3,36 menggunakan skala Likert 1-5 (1= (hampir) selalu BSs dan $5=$ (hampir) selalu BI, sedang 3 = sama seringnya Bahasa Sasak (BSs) dan Bahasa Indonesia (BI). Ini berarti pula bahwa pilihan jawaban responden yang menyatakan pernah dan tidak pernah serta yang tidak menyatakan pendapat boleh jadi menggunakan BSs dan BI sama banyaknya ketika berkomunikasi dengan para pegawai/tata usaha di sekolah. Wilian (ibid) menyatakan bahwa kecenderungan generasi muda yang hampir mendekati 'lebih sering BI daripada BSs' disebabkan oleh fakta bahwa BI lebih fleksibel, lebih netral daripada BSs, karena bahasa Sasak mengandung adanya 'tata krama bahasa' atau dalam istilah Sasak bebase atau undha usuk. Ini berarti ketika seseorang berbicara dengan orang yang dihormati, lebih tua, atau secara sosial mempunyai kedudukan lebih tinggi, ia harus mempertimbangkan pilihan kata-katanya terlebih dahulu.

\section{Penguasaan Kosa Kata Alus dan Kemampuan Menyusun Kalimat}

Berdasarkan data kuantitatif hasil tes penguasaan kosa kata halus dan tes kemampuan menyusun kalimat BSsA responden diperoleh bahwa skor rata-rata penguasaan kosa kata halus mereka, berdasarkan kelompok usia, berkisar antara 50,52 untuk kelompok usia 10-15 tahun dan 65,50 untuk kelompok usia 31-35 tahun. Berdasarkan kriteria penilaian yang sudah ditentukan skor 50,52 masuk pada kelompok kategori II (46-55) = kurang, sedangkan untuk kelompok usia 3135 tahun dengan skor 65,50 termasuk pada kelompok kategori III ( 56-69) = cukup. Namun demikian untuk penguasaan kosa kata halus sehari-hari mereka untuk menyatakan kesopanan boleh dikatakan cukup karena sebagian mereka masih mengerti kosa kata halus yang sering mereka dengar dan digunakan masyarakat, seperti tiang 'saya', nggih 'ya', silaq 'silakan', sampun 'sudah', niki-nike 'ini-itu', dan beberapa yang lain. Akan tetapi untuk kosa kata halus yang berupa nomina dan adjektiva seperti lumbar untuk lalo 'pergi', lingsir untuk toaq 'tua', hanya sebagian kecil dari mereka yang tahu. Meskipun demikian, berdasarkan data hasil tes penguasaan kosa kata halus responden seperti ditampilkan pada Tabel 5, tampak bahwa semakin tua usia responden semakin tinggi rerata penguasaan kosa kata halus mereka walaupun skalabilitasnya tidak mencapai $100 \%$, karena menurunnya skor pada kelompok usia 21-25 tahun. Begitu pula, semakin tinggi tingkat pendidikan responden tampak semakin baik penguasaan kosa kata halus mereka.

Tabel 5. Skor rerata penguasaan kosa kata halus berdasarkan usia dan pendidikan

\begin{tabular}{cccc}
\hline Usia & Skor & Pendidikan & Skor \\
\hline $11-15$ tahun & 50,52 & Tidak pernah sekolah & 28,00 \\
\hline $16-20$ tahun & 55,84 & SD & 44,00 \\
\hline $21-25$ tahun & 51,03 & SMP & 53,89 \\
\hline $26-30$ tahun & 63,55 & SMA & 57,53 \\
\hline $31-35$ tahun & 65,50 & Perguruan Tinggi & 67,99 \\
\hline
\end{tabular}


Berdasarkan analisis statistik pemakaian tindak tutur (TT), ternyata mereka yang tidak pernah menggunakan BSsA di dalam keluarganya pun juga mengetahui dan mengerti sebagian kecil leksikon BSsA tersebut, walaupun tingkat kemampuan mereka masuk dalam kategori sangat rendah. Hal ini dapat dilihat pada data agregat rerata skor penguasaan kosa kata dan kemampuan menyusun kalimat BSsA responden berdasarkan kekerapan menggunakan BSsA dengan orang tua dan famili lainnya di rumah (Gambar 2). Berdasarkan data ini dapat diketahui bahwa semakin sering responden menggunakan BSsA maka semakin tinggi tingkat penguasaan kosa katanya. Sebagaimana dapat dilihat pada Gambar 2, bahwa yang 'tidak pernah' menggunakan atau mungkin 'tidak tahu' tentang TT pun mendapat rerata skor penguasaan kosa kata sebesar 40,09, sedangkan yang 'selalu' menggunakan TT mendapat skor 71,43.

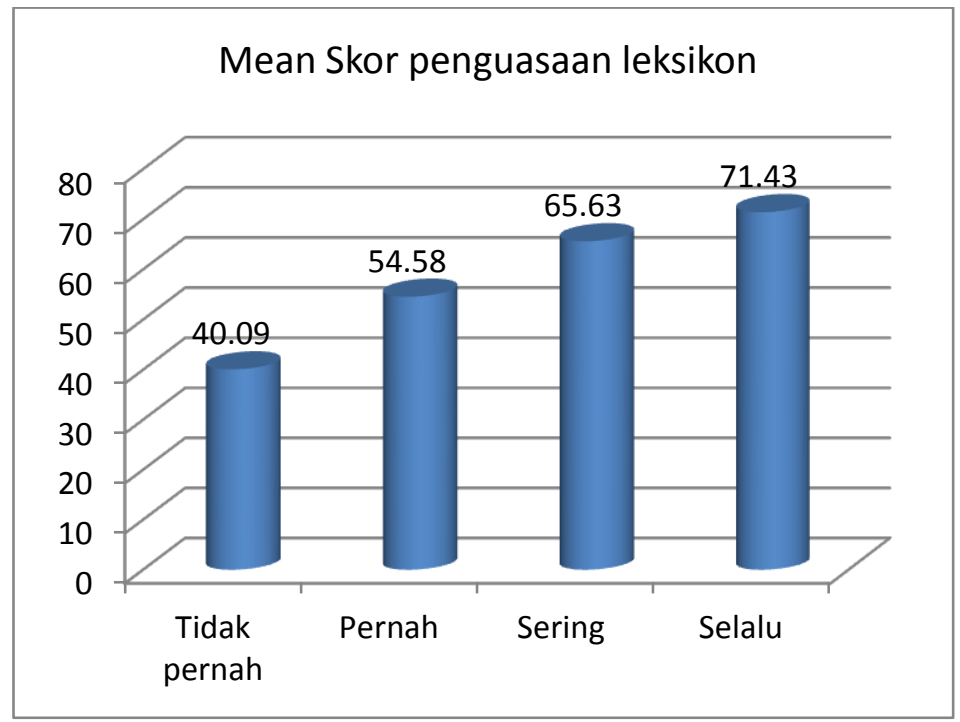

\section{Gambar 2. Grafik rerata skor penguasaan leksikon berdasarkan kekerapan menggunakan BSsA dengan keluarga di rumah}

Demikian pula dalam hal kemampuan menyusun kalimat BSsA, semakin sering atau semakin intens responden menggunakan TT BSsA semakin tinggi rerata skor menyusun kalimat BSsA-nya. Gambar 3 di bawah ini menunjukkan bahwa mereka yang 'tidak pernah' menggunakan TT namun sering mendengarnya memperoleh rerata skor penyusunan kalimat sebesar 33,23. Sementara mereka yang 'selalu' menggunakan, rerata skornya 67,64, dan yang 'pernah' dan 'sering' rerata skornya berada di tengah-tengah, yaitu 54,58 dan 65,63.

Sebagai aspek penting yang sangat menentukan dalam mengukur tingkat kebertahanan atau pergeseran tingkat tutur sebuah bahasa, maka seberapa jauh penutur sebagai pemilik dan pewaris bahasa menguasai dan memahami pemakaian TT bahasanya dalam kalimat sangat penting untuk diketahui. Sama halnya dengan penguasaan kosa kata, penguasaan dalam menyusun kalimat BSsA berdasarkan kelompok usia tampak adanya skalabilitas peningkatan skor berdasarkan kelompok usia. Semakin dewasa kelompok usia penutur akan relatif semakin baik tingkat pemahaman penggunaan BSsAnya. 


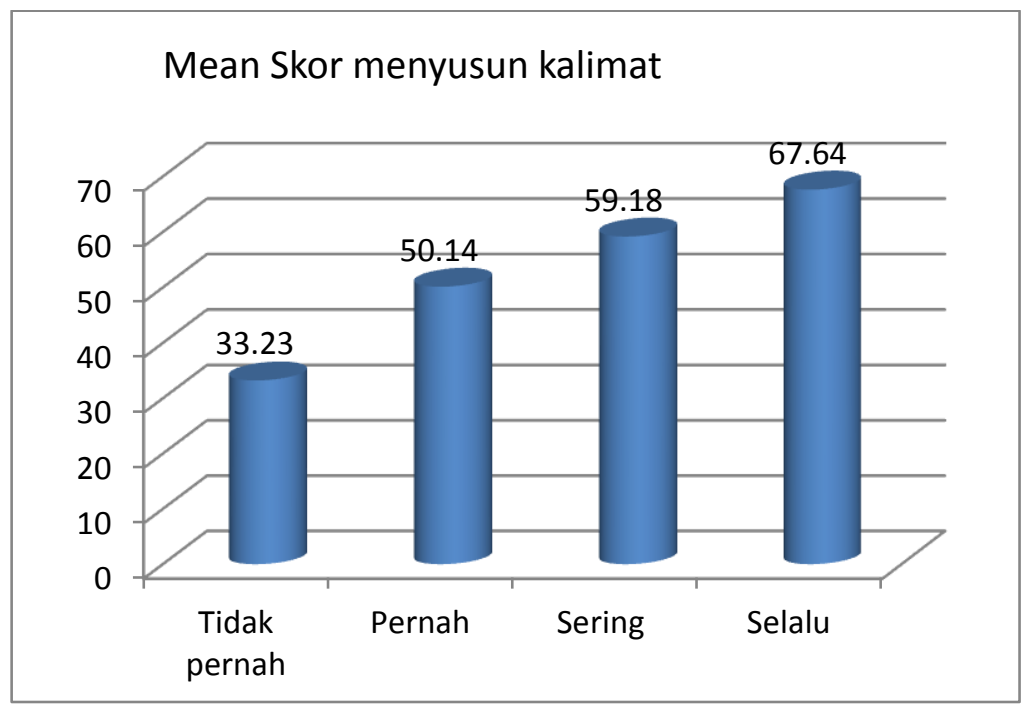

\section{Gambar 3. Grafik rerata skor kemampuan menyusun kalimat berdasarkan kekerapan menggunakan BSsA}

Secara umum rerata skor kemampuan menyusun dan menggunakan kalimat BSsA dari kelompok usia paling rendah 10-15 tahun (pra remaja) ke kelompok usia dewasa 31-35 tahun (kelompok dewasa) dimulai dari 42,47 sampai dengan 61,63, walaupun hal ini juga tidak menunjukkan adanya skalabilitas $100 \%$ (lihat Gambar 4). Secara metodologis keadaan seperti ini dapat saja terjadi yang kemungkinan disebabkan oleh kesalahan sampling atau fakta di lapangan memang menunjukkan demikian. Artinya bisa saja terjadi bahwa rerata skor penguasaan menyusun kalimat BSsA kelompok usia SLTP dan SLTA tidak jauh berbeda dari kelompok usia di atasnya sebab jika dilihat dari skor maksimum masing-masing kelompok usia juga hampir sama.

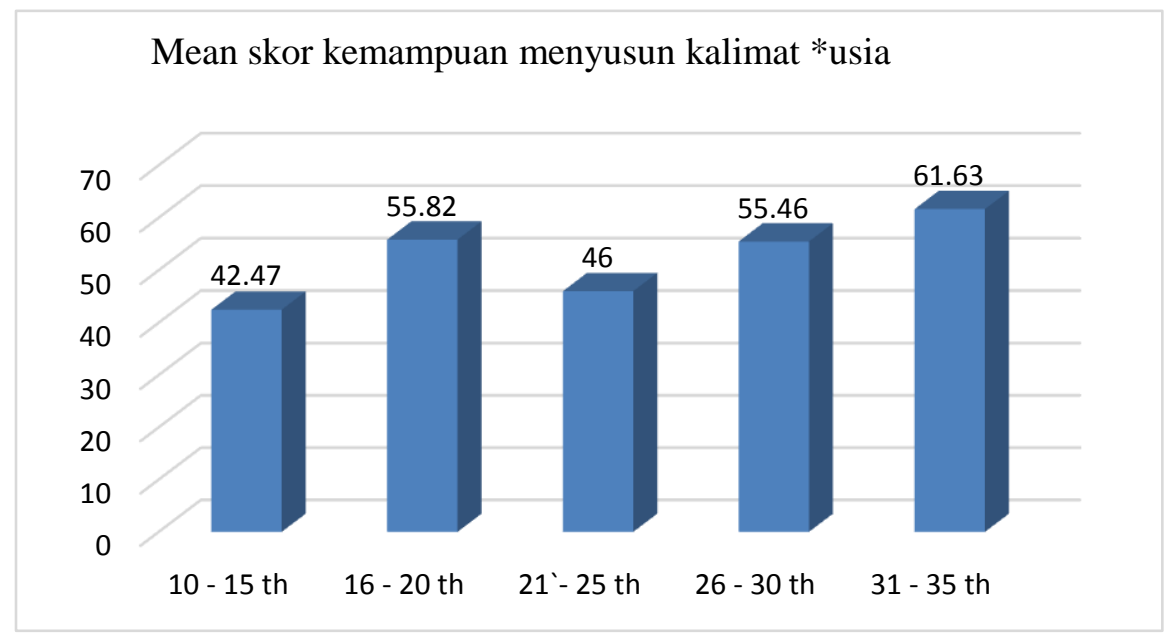

Gambar 4. Grafik rerata skor mean kemampuan menyusun kalimat menurut usia

Dapat dikatakan bahwa berdasarkan pengamatan peneliti, yang juga penutur bahasa Sasak, rata-rata keluarga dengan status sosial ekonomi rendah sangat jarang, bahkan hampirhampir tidak pernah mengajarkan kosa kata BSsA kepada putra-putri mereka, sebagaimana terekam pada data statistik "kekerapan penggunaan BSsA kepada anak/anggota keluarga pada 
responden yang sudah berkeluarga" sebagaimana ditampilkan pada Gambar 5 di bawah ini. Hal ini mengimplikasikan bahwa TT BSs tidak banyak dikenal (digunakan) di kalangan masyarakat yang disebut golongan jajarkarang/non-menak (bukan bangsawan). Ini berarti pula bahwa jika semakin banyak generasi muda tidak pernah diperdengarkan atau diajarkan TT BSs maka besar kemungkinan pula TT itu lama kelamaan akan pudar dan tidak akan pernah sampai terdengar oleh telinga kaum jajarkarang.

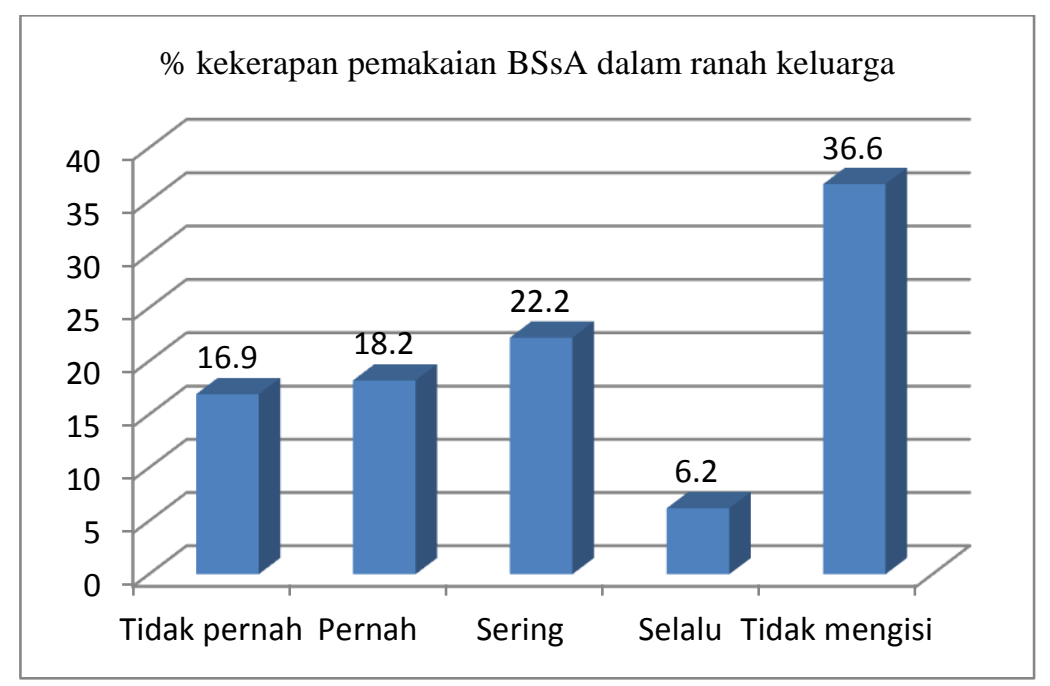

\section{Gambar 5. Persentase kekerapan penggunaan BSsA kepada anak/anggota keluarga oleh responden yang sudah berkeluarga}

Walaupun demikian, dari segi sikap responden terhadap TT BSsA hampir lebih dari separuh responden $(50,5 \%)$ sangat setuju bahwa BSsA dapat mengajarkan tata krama berbahasa, dan $45,8 \%$ menyatakan setuju. Hanya ada $0,6 \%$ yang tidak setuju dan 3,1\% yang tidak menyatakan pendapatnya. Dengan demikian dapat dikatakan bahwa TT dalam BSs memang masih diperlukan oleh penuturnya dan karenanya perlu tetap dipertahankan. Meskipun banyak di antara responden yang menyatakan tidak pernah menggunakan BSsA dengan keluarga atau famili lainnya di rumah, ini tidak berarti bahwa mereka sama sekali tidak bisa berbahasa alus. Banyak kata yang menurut beberapa informan dipahami bila diperdengarkan, namun jika akan digunakan sendiri sulit untuk diucapkan, karena takut salah.

\section{Faktor-Faktor Pergeseran Pemakaian BSsA}

Ada beberapa faktor yang tampaknya sangat berpengaruh terhadap tidak berkembangnya pemakaian BSA dalam masyarakat, yang memicu kemungkinan bergesernya tingkat tutur itu khususnya di kalangan generasi muda. Secara umum dapat disebut adanya faktor internal dan eksternal. Yang termasuk faktor internal adalah lingkungan keluarga, lingkungan masyarakat, lingkungan sekolah, sedangkan faktor eksternal adalah pengaruh pemakaian bahasa Indonesia dan pergeseran nilai-nilai yang ada dalam masyarakat, terutama aturan adat yang melonggarkan aturan perkawinan antar golongan/strata sosial, antara golongan 'ningrat' (priyayi) dan kalangan ‘jajarkarang’ (golongan biasa).

Lingkungan Keluarga. Dalam hampir semua keluarga yang disebut commoners atau jajarkarang sangat jarang diajarkan kepada anak-anak dan keluarga mereka tentang bahasa 
halus, sekalipun sekedar mengatakan tiang-nggih untuk 'saya-ya' sebagai bentuk halus dari elae/welape-aoq (bergantung pada dialek) dalam merespon panggilan orang tua sejak anak mulai tumbuh kembang. Itu pula sebabnya responden mengatakan bahwa mereka jarang mendengar orang berbahasa halus, kecuali pada acara pertemuan tertentu, yang dalam tulisan ini dan sebelumnya penulis sebut sebagai ranah situasi tertentu, misalnya bertemu dengan tokoh agama, orang yang dituakan atau dihormati (tuan guru, golongan menak, pejabat pemerintah, dll) atau kadang saat berbelanja di pasar atau toko, atau bertegur sapa dengan orang yang baru dikenal. Kalaupun ada keluarga yang terus menggunakan BSsA di rumah hanya terbatas pada kalangan keluarga menak saja. Yang lainnya hanya sangat kecil jumlahnya, sehingga sebenarnya tidak dapat dianggap meluas pemakaiannya pada seluruh lapisan masyarakat di Lombok sebagaimana diklaim oleh Nothofer (2000) dalam P.K. Austin (ed.) Sasak: Working Papers in Sasak, yang disejajarkan dengan pemakaian TT dalam bahasa Jawa.

Kurangnya perhatian orang tua terhadap pemakaian kosakata halus di dalam keluarga tentu berpengaruh sangat besar pada lemahnya pemahaman generasi muda baik terhadap kosa kata halus itu maupun pemakaiannya dalam konteks kalimat. Dari hasil survei kekerapan pemakaian BSsA dalam keluarga untuk semua responden menunjukkan hanya 8,3\% responden yang memperkenalkan kosa kata halus kepada sanak keluarganya, 18,2\% menyatakan sering, dan sebagian besar $(59,7 \%)$ hanya menyatakan pernah, serta $13,8 \%$ malah tidak pernah mendengar orangtua mereka berbicara dalam BSsA. Maka tidaklah mengherankan apabila tidak semua masyarakat golongan bawah (Jajarkarang) mengetahui bentuk-bentuk tingkat tutur itu, karena memang mereka jarang mendengarnya dalam hubungan sosial sehari-hari kecuali dalam keadaan atau situasi yang sangat langka, misalnya bertemu dengan tokoh agama (Tuan Guru) atau pejabat pemerintahan sebagaimana disebutkan di atas. Kalaupun masyarakat bawah ini mengetahui beberapa kosakata, hanya terbatas pada kata-kata pronomina pertama dan kedua seperti tiang 'saya', dan plungguh 'Anda', atau kata-kata penghalus inggih 'ya', silak 'silakan, mari', dan sampun 'sudah'. Di samping itu, sudah lama tertanam dalam pikiran masyarakat secara luas bahwa TT dalam BSs itu identik dengan pemakaian bahasa pada masyarakat golongan bangsawan (perwangsa/menak). Jadi, pemakaian ragam bahasa tersebut hanya pada golongan masyarakat tersebut dan ditambah pada sebagian anggota masyarakat yang terdidik. Dengan demikian faktor lingkungan pemakaiannya itulah yang berperan di sini. Semakin banyak masyarakat bergaul dan berhubungan dengan para 'priyayi' Sasak dan golongan bangsawan itu semakin besar peluang masyarakat untuk menguasai ungah-ungguh ing base Sasak itu.

Lingkungan Sekolah. Tidak dapat dipungkiri bahwa lingkungan di sekolah juga ikut memberi pengaruh pada kemampuan anak-anak dalam menguasai bahasa ibu mereka sendiri, khususnya dalam memahami seluk beluk leksikal alus dan pemakaiannya. Dalam kurikulum pelajaran Bahasa Sasak yang diberikan di sekolah-sekolah tampak bahwa bahasa Sasak yang diajarkan adalah BSs yang paling umum saja, yaitu sekedar untuk memenuhi tuntutan muatan lokal. Kemudian pendekatan pengajarannya pun tampak sangat struktural. Tidak ada latihan percakapan atau penyusunan kalimat yang mengajarkan pemakaian kosa kata halus, walaupun di sana banyak tercantum kosa kata halus. Dengan kata lain pendekatan pengajaran secara kontekstual pragmatis tidak terlihat. Yang ada malah penjelasan tentang susunan hukum DM (diterangkan dan menerangkan) dalam bahasa Sasak dan belajar struktur kalimat bahasa Sasak, kalimat tunggal, kalimat majemuk (lihat Perajahan Base Sasak, SMP Negeri 2 Mataram, 2007). 
Selain itu isi pelajaran juga banyak memuat pelajaran sastra dan budaya Sasak. Hal ini dapat dilihat dari banyaknya materi Sesenggak (peribahasa Sasak) dan bacaan sastra yang ada dalam buku-buku yang dipakai. Di satu sisi materi pelajaran tersebut cukup memberikan pemahaman kepada siswa tentang kebudayaan Sasak, tetapi pada sisi yang lain isi pelajaran belum menyentuh tata krama berbahasa (sopan santun) yang banyak dinyatakan dengan pemakaian kosakata halus atau yang disebut tingkat tutur itu. Selain itu, berdasarkan penelusuran yang dilakukan peneliti, tidak semua sekolah menengah pertama di Kota Mataram mengajarkan mulok Bahasa Sasak, apa lagi di seluruh Lombok.

\section{Pengaruh Pemakaian Bahasa Indonesia dan Kedwibahasaan Usia Dini}

Pengaruh pemakaian Bahasa Indonesia yang begitu meluas pada setiap aspek kehidupan juga tidak dapat diabaikan ikut memberikan andil ditinggalkannya pemakaian TT dalam bahasa daerah. Dalam perkembangan saat ini bagi sebagian besar generasi muda dari kebanyakan masyarakat biasa, pemakaian leksikon alus ini pun sangat jarang terdengar. Alih-alih menggunakan TT, kebanyakan remaja dan pemuda Sasak menggunakan Bahasa Indonesia, karena dianggap lebih netral. Justru dengan menggunakan bahasa Indonesia mereka beranggapan akan lebih sopan dan terkesan lebih modern, sebagaimana terekam dari hasil pengamatan dan wawancara dengan beberapa remaja ketika ditanya bahasa apa yang dipakai jika berkunjung ke kantor desa atau camat. Salah seorang dari mereka mengatakan: "Saya agak canggung menggunakan bahasa Sasak dengan orang-orang di tempat dinas, takut salah. Di samping karena belum kenal, rasanya lebih sopan memakai bahasa Indonesia. Selain itu, petugasnya juga lebih dahulu menyapa kita dengan bahasa Indonesia. Jadi kita juga jawabnya dalam bahasa Indonesia, meskipun di rumah saya menggunakan bahasa Sasak dengan orang tua dan semua keluarga, dan tetangga saya." Ada pula yang menjawab (seorang mahasiswi): "Kami merasa lebih terhormat dan terkesan berpendidikan kalau memakai bahasa Indonesia, daripada bahasa Sasak. Kami merasa agak malu kalau menggunakan bahasa Sasak. Apalagi kantor itu kan situasi formal."

Jadi ada kemungkinan dipilihnya BI dari pada BSs karena ada faktor situasi dan psikologis bahasa yang menganggap BI lebih bergengsi (sebagai bahasa $\mathrm{T}$ dalam konteks masyarakat bilingual atau multilingual) daripada bahasa daerah. Selain itu, mereka lebih mudah mengutarakan pikiran mereka dalam BI daripada BSs atau lebih-lebih dalam BSsA. Mereka merasa lebih percaya diri dalam berkomunikasi menggunakan BI dan tidak terbebani dengan kesalahan penggunaan TT dan kosa kata BSsA sebagaimana banyak disampaikan oleh responden. Disamping itu nilai rasa kebahasaan menggunakan BI lebih egaliter daripada bahasa daerah yang mengandung tingkat tutur dan masih berbau 'feodalistik'. Hal ini dapat dilihat dari hasil penelitian Wilian (2009) yang memaparkan kecenderungan pemilihan BI masyarakat berdasarkan kelompok usia. Semakin muda kelompok usia masyarakat semakin besar kecenderungannya menggunakan $\mathrm{BI}$, dan semakin tinggi tingkat pendidikannya semakin tinggi pula kecenderungan menggunakan BI. Selain itu faktor pesatnya perkembangan pemakaian BI di berbagai ranah juga ikut memicu memperlemah hasrat generasi muda mendalami pemakaian BSsA. Alih-alih itu, mereka cukup menggunakan BI saja yang malah dianggap lebih sopan jika tidak ingin salah dalam menggunakan BSsA.

Selain semua itu, keharusan guru menggunakan Bahasa Indonesia sebagai bahasa pengantar pengajaran di tingkat pendidikan anak usia dini (PAUD) atau di kelas rendah sekolah dasar, baik di kota-kota kabupaten dan provinsi maupun di pelosok-pelosok desa, juga ikut 
memicu keengganan guru-guru menggunakan bahasa ibu sebagai bahasa pengantar pengajaran di sekolah. Salah satu sebabnya adalah tidak adanya payung hukum dari instansi pemerintah terkait yang menaungi pemakaian bahasa daerah itu sendiri sebagai bahasa pengantar pengajaran di kelas rendah. Akibatnya adalah anak-anak pun tidak pernah dapat didemonstrasikan bagaimana berbahasa daerah yang baik dan benar sesuai tingkat perkembangan usia anak. Pada gilirannya setelah anak menjadi remaja dan dewasa mereka pun tidak dapat memahami seluk beluk bahasa ibu mereka yang menjadi akar budaya masyarakat dimana mereka dilahirkan. Orangtua dari anak-anak yang masuk PAUD di desa-desa pun merasa lebih bangga melihat putra-putri mereka lancar berbahasa Indonesia lebih awal daripada BSsA, yang memicu anak-anak menjadi bilingual sejak dini yang secara psikolinguistik hal itu menguntungkan. Namun, itulah harga yang harus dibayarkan oleh anak-anak dan orangtua sehingga secara tidak sadar sampai mengabaikan dan tidak-mempedulikan jati dirinya sebagai penutur bahasa daerahnya sendiri.

\section{Variasi (Dialek) Bahasa Sasak yang Cukup Beragam}

Setidaknya ada lima dialek yang cukup dapat dikenali oleh penutur bahasa Sasak. Masingmasing penutur dialek masih dapat saling memahami satu sama lainnya (mutually intelligible). Dialek-dialek tersebut dikenal dengan nama-nama Ngeno-ngene, Meno-mene/i, Nggeto-nggete, Meriak-meriku, dan Kuto-kute, yang berarti 'begini-begitu', dan masing-masing juga dikenal dengan sebutan sesuai daerah pakainya, yaitu berturut-turut dialek Selaparang, Pejanggik (Praya), Suralaga, Pujut, dan Tanjung/Bayan. Sebagai akibatnya dalam penyusunan bahan ajar yang seragam agak sulit dilakukan, karena terutama adanya perbedaan leksikon tertentu, perbedaan leksikogramatika, dan ciri-ciri prosidi (prosody features) yang terdapat pada masingmasing dialek. Akan tetapi, dialek yang paling umum dikenali oleh masyarakat adalah dialek Meno-mene/i, disusul oleh dialek Ngeno-ngene, karena dialek tersebut umumnya digunakan di radio-radio dan televisi lokal, baik oleh penyiar maupun dalam percakapan di sandiwara (lihat Wilian dkk, 2017). Permasalahannya adalah sampai saat ini belum ada kesepakatan dan kesepahaman di antara berbagai penutur dialek itu untuk menggunakan transkripsi dialek yang mana di dalam buku-buku pelajaran bahasa Sasak yang akan dipakai.

\section{Pergeseran Nilai-Nilai dalam Masyarakat}

Harus diakui bahwa adanya lapisan-lapisan sosial dalam masyarakat di Lombok berpengaruh pula terhadap keadaaan kebahasaannya, sebagaimana juga terjadi di berbagai tempat di Indonesia (lihat Poedjasoedarma dkk. 1979; Geertz, 1983:333-348) dan dalam masyarakat mana pun di dunia ini. Satu golongan atau lapisan masyarakat dapat menganut aturan berbicara atau berkomunikasi dengan sesama menggunakan variasi atau ragam bahasa yang 'lebih tinggi' dan yang lainnya menggunakan variasi atau ragam yang 'lebih rendah' atau biasa. Dua lapisan masyarakat pemakai variasi bahasa yang berbeda itu boleh jadi berlanjut pada hubungan perkawinan. Hal inilah kemudian yang dapat memicu adanya perubahan nilai-nilai dalam cara pandang penggunaan bahasa. Demikian pula yang terjadi dalam masyarakat Sasak di Lombok. Adanya perubahan nilai dalam sistem perkawinan antara keluarga bangsawan dan nonbangsawan Sasak juga berimbas pada longgarnya tata krama pemakaian Base Alus itu sendiri. Akan tetapi, keluarga bangsawan yang masih secara konsisten menggunakan tingkat tutur di 
antara anggota keluarga mereka dapat mempertahankannya dan menggunakannya dengan lebih baik, namun jumlahnya sangat terbatas, hanya pada kalangan keluarga bangsawan itu sendiri.

\section{Kurangnya Dukungan (Perhatian) Pihak Pemerintah}

Tidak adanya dukungan dan kebijakan instansi pemerintah terkait dengan bidang pendidikan (Dinas Pendidikan dan Kebudayaan) untuk mewajibkan pembelajaran bahasa daerah sebagai muatan lokal (mulok) terutama pada sekolah menengah pertama dan juga pada madrasahmadrasah tsanawiyah yang jumlahnya cukup banyak sampai di pelosok-pelosok desa juga ikut mempersuram eksistensi bahasa daerah, termasuk pula pembelajaran tingkat tuturnya. Salah satu alasan yang diberikan, berdasarkan hasil wawancara peneliti dengan pihak dinas pendidikan, adalah tidak adanya atau belum tersedianya naskah akademik tentang pemakaian bahasa Sasak standar yang akan dijadikan rujukan bagi guru-guru atau penulis bahan ajar dalam menyusun materi bahan ajar bahasa Sasak itu. Mengingat adanya variasi-variasi dialek yang ada membuat guru cenderung menyusun bukunya berdasarkan dialek yang diketahuinya, walaupun ini tentu juga dapat dipahami. Itu pula sebabnya pihak dinas pendidikan sangat mengharapkan partisipasi dan sumbangan pemikiran dunia perguruan tinggi untuk meneliti dan membantu mengembangkan materi bahan ajar terstandar berdasarkan kajian-kajian yang dilakukan, sehingga dengan demikian naskah akademik kurikulum dan sillabus pelajaran BSs yang juga memuat BSsA dapat disusun. Permasalahannya, sejak beberapa tahun terakhir pelajaran mulok bahasa daerah itu sendiri justru malah dihapus karena bahasa daerah dianggap tidak penting. Pihak sekolah bahkan dibebaskan untuk memilih beberapa pilihan keterampilan, seperti kerajinan, memasak, dan bahasa Inggris sebagaimana diamanatkan dalam kurikulum sekolah menengah.

\section{Pengaruh Perkembangan Pariwisata}

Pengaruh perkembangan pariwisata yang begitu cepat dalam kurun waktu sepuluh tahun terakhir ikut memicu ditawarkannya mulok bahasa Inggris sebagai pengganti bahasa Sasak di beberapa sekolah, khusunya di Kota Mataram. Menurut informasi dari sebuah sekolah menengah di kota ini, sejak lima tahun terakhir sekolah ini mengganti mulok bahasa daerah dengan keterampilan memasak dan kerajinan. Bahkan ada beberapa sekolah dasar yang menggantinya dengan bahasa Inggris dengan alasan untuk memperkenalkan anak-anak dengan bahasa asing itu sejak dini. Alasan lainnya karena tidak adanya guru yang bersedia mengajar mulok bahasa Sasak, selain tidak adanya buku pegangan yang memadai yang dapat dipakai sebagai pedoman.

\section{SIMPULAN}

Salah satu aspek kebahasaan yang dapat dilihat untuk menilai kemampuan atau penguasaan seseorang terhadap suatu bahasa adalah penguasaan kosa katanya. Poedjasoedarma dkk (1979) mengatakan bahwa penguasaan TT ditentukan berdasarkan jenis dan jumlah leksikon TT dalam sebuah kalimat. Berdasarkan pendapat tersebut maka pergeseran TT BSsA dalam BSs ini juga dapat dilihat dari penguasaan leksikon TT para penuturnya, selain ditentukan pula oleh kemampuan menggunakannya dalam situasi bertutur yang sesungguhnya. Hal ini berarti pula bahwa jika terjadi degradasi atas penguasaan kosa kata bahasa yang dikuasainya, maka hal itu akan menunjukkan pula terjadinya pergeseran pemakaian TT bahasa tersebut. Dalam hal 
penelitian ini, aspek penguasaan kosa kata halus BSs itu juga sangat penting untuk dilihat. Selain itu berdasarkan pemaparan data statistik yang ditunjukkan pada tabel dan gambargambar pemakaian TT BSsA dalam beberapa ranah pemakaian bahasa (domain of language use) sebagai faktor internal pemertahanan bahasa/variasi bahasa di atas dapat dirampatkan bahwa ada kecenderungan semakin muda kelompok usia responden semakin kecil rerata skor atau rata-rata nilai penguasaan kosa kata dan kemampuan menyusun kalimatnya. Sebaliknya, semakin tua kelompok usia semakin tinggi penguasaan kosa kata halus dan kemampuan menyusun kalimat BssA-nya. Dapat pula dilihat bahwa kekerapan dan pengenalan pemakaian TT sejak dini dalam lingkungan keluarga dan masyarakat akan sangat mempengaruhi kemampuan menggunakan TT itu, dan pada akhirnya akan mempengaruhi tingkat kebertahanan variasi bahasa itu. Umumnya dalam literatur pergeseran bahasa ada skalabilitas pergeseran dari kelompok usia yang lebih tua ke kelompok usia yang lebih muda, dalam arti semakin muda kelompok usia semakin rendah tingkat penguasaan kosa kata dan kemampuan menggunakan BSsAnya.

Ada banyak faktor yang menyebabkan pergeseran pemakaian tingkat tutur itu terjadi di kalangan generasi muda Sasak di Lombok, dan yang paling menonjol adalah faktor lingkungan, baik lingkungan keluarga maupun lingkungan sekolah dan masyarakat secara umum. Generasi muda tampak tidak peduli dengan BSsA karena secara turun temurun BSsA jarang diperdengarkan di tengah-tengah kalangan keluarga jajarkarang (masyarakat biasa) atau 'commoners' atau bahkan tidak pernah diperdengarkan sama sekali. Faktor pengaruh perembesan pemakaian bahasa Indonesia ke dalam domain-domain yang sebenarnya merupakan wilayah pakai bahasa daerah juga ikut memperlemah posisi bahasa daerah dan sekaligus tingkat tuturnya, termasuk di sini juga 'kewajiban' guru-guru pada pendidikan Taman Kanak-Kanak memperkenalkan bahasa Indonesia pada usia dini. Selain itu terdapat pula faktor-faktor pergeseran nilai-nilai dalam masyarakat yang dipicu oleh perkawinan antar kelompok sosial masyarakat, kemudian pengaruh variasi dialek bahasa Sasak yang cukup beragam, dan kurangnya dukungan pihak pemerintah terhadap pembelajaran BSs sebagai muatan lokal, serta faktor pengaruh perkembangan pariwisata di Lombok.

Penelitian ini juga menemukan bahwa masyarakat Sasak cenderung menggunakan BI jika diajak berbicara BSsA. Kecenderungn itu bukan tanpa alasan, sebagian mengatakan karena takut salah dan kosa kata bahasa alus mereka sangat terbatas sehingga lebih nyaman jika memakai BI. Sebagian lagi mengatakan karena memang tidak bisa BSsA dengan alasan karena memang jarang sekali mendengar orang berbahasa alus. Hasil penelitian ini juga menunjukkan bahwa apa yang sesungguhnya dikhawatirkan selama ini oleh banyak pihak, terutama orangorang tua bahwa generasi muda tidak lagi mampu menggunakan bahasa alus dengan baik dan benar tampaknya menjadi kenyataan. Ini berarti bahwa diperkirakan dalam waktu yang tidak lama lagi dalam beberapa generasi, jika tidak ada upaya yang dilakukan untuk merevitalisasinya di kalangan generasi muda, TTBS akan menghilang walaupun tidak secara keseluruhan.

\section{CATATAN}

* Penulis berterima kasih kepada mitra bestari yang telah memberikan saran-saran dan masukan yang sangat berarti untuk perbaikan tulisan ini. 


\section{DAFTAR PUSTAKA}

Abhari, S. (2009). Bahasa penyilaqan dalam kasta masyarakat desa Durian, Kecamatan Janapria Lombok Tengah: Suatu kajian etnografi komunikasi. Skripsi, FKIP Universitas Mataram.

Azhar, L.M. (1996). Reramputan pelajaran bahasa Sasak: Untuk kelas 3 SLTP. Klaten: PT Intan Pariwara.

BPS NTB, (2010). Hasil sensus penduduk 2010 Prov. Nusa Tenggara Barat. Mataram: BPS NTB.

Clynes, A. (1994). Old Javanese influence in Balinese: Balinese speech styles. Dalam T. Dutton \& D.T. Tryon (eds.). Language contact and change in the Austronesian world, hlm. 141-179. Berlin, New York: Mouton de Gruyter.

Fishman, J.A. (1972a). Language maintenance and language shift. Dalam J.A. Fishman Language in the sociocultural change. Stanford: Stanford University Press.

(1972b). The Sociology of Language: An Interdisciplinary Social Science Approach to Language in Society. Massachusetts: Newbury House Publishers.

Gu, Y. (1990). Politeness phenomena in modern Chinese. Dalam Journal of Pragmatics 14: 237-257.

Gunarwan, A. (2001a). Indonesian and Balinese among native speakers of Balinese: A case of stable bilingualism? Makalah pada Third International Symposium on Bilingualism, Bristol, U.K., 17-20 April 2001.

. (2001b). Indonesian and Banjarese Malay among Banjarese ethnics in Banjarmasin city: A case of diglosia leakage? Makalah pada Simposium Internasional V tentang Linguistik Melayu/Indonesia. Leipzig, Jerman, 16-17 Juni 2001.

Hafifah. (2009). Tingkat tutur bahasa Sasak pada masyarakat Tanak Awu, Kecamatan Pujut. Skripsi, FKIP Universitas Mataram.

Holmes, J. (1992). An introduction to sociolinguistics. New York: Longman Publishing.

Husaini, Bq. N. (2014). The analysis of factors influencing the decreasing use of Base Alus among teenagers in Lendang Ape Sub-Village. Skripsi, FKIP Universitas Mataram.

Mackey, W.F. (1962). Sociolinguistic studies in language contact: Method and cases. New York: Mouton.

Martin, S.E. (1964). Speech levels in Japan and Korea. Dalam Dell Hymes (ed.). Language and culture in society: A reader in linguistics and anthropology. New York: Harper \& Row Publishers.

Mesthrie, R. dan W.L. Leap. (2000). Language contact 1: Maintenance, shift and death. Dalam R. Mesthrie, et. al. Introducing sociolinguistics. Edinburg: Edinburg University Press.

Nothofer, B. (2000). A preliminary analysis of the history of Sasak language level. Dalam P.K. Austin (ed.). Sasak: Working Papers in Sasak, hlm.57-84. Department of Linguistics and Applied Linguistics, The University of Melbourne. 
Paridi, K., S. Wilian, I N. Sudika. (2017). Identifikasi dan kodifikasi dialek bahasa Sasak standar dalam baca tulis mata pelajaran bahasa Sasak: Pengembangan buku ajar muatan lokal berbasis bahasa standar. Laporan Penelitian: Lembaga Penelitian dan Pengabdian kepada Masyarakat, Universitas Mataram.

Prihartini, Bq. A. (2006). Pengaruh makna tingkat tutur dalam bahasa Sasak dan hubungannya dengan nada pilihan bahasa masyarakat desa Sakra, Kabupaten Lombok Timur. Skripsi, FKIP Universitas Mataram.

Poedjosoedarmo, S. dkk. (1979). Tingkat tutur bahasa Jawa. Jakarta: Depdikbud.

Sariono, A. (2002). Tingkat tutur bahasa Jawa di Diponggo: Menuju ke kepunahan. Dalam Jurnal Ilmu Bahasa dan Sastra, Vol. 2(1), Januari-Juli 2002

Siregar, B.U, dkk. (1998). Pemertahanan bahasa dan sikap bahasa: Kasus masyarakat bilingual di Medan. Pusat Pembinaan dan Pengembangan Bahasa, Jakarta.

Rahardi, R.K. 2001. Sosiolinguistik, kode dan alih kode. Yogyakarta: Pustaka Pelajar

Subroto, D.E. dkk. (2008). Endangered Krama and Krama Inggil varieties of the Javanese language. Dalam Linguistik Indonesia. Tahun ke-26, No. 1: 89-96.

Wilian, S. (1995). Forms of address in Sasak language. Dalam AKSARA. Denpasar: Pusat Bahasa-Depdikbud Prov. Bali.

. (2005). Bahasa minoritas, identitas etnis, dan kebertahanan bahasa: Kasus bahasa Sumbawa di Lombok. Dalam Linguistik Indonesia. Tahun ke-23 No.1: 89-102.

. (2006a). Tingkat tutur dalam bahasa Sasak dan bahasa Jawa. Dalam Wacana. Tahun 2006. Vol. 8 No.1.

. (2006b). Pemertahanan bahasa dan pergeseran identitas etnis: Kajian atas dwibahasawan Sumbawa-Sasak di Lombok. Disertasi. Universitas Indonesia.

(2010). Pemertahanan bahasa dan kestabilan kedwibahasaan pada penutur bahasa Sasak di Lombok. Dalam Linguistik Indonesia. Tahun ke-28, Nomor 1: 23-39.

\footnotetext{
${ }^{1}$ kepembayunan merupakan istilah yang digunakan dalam upacara Sorong Serah (suatu rangkaian acara penyerahan pengantin wanita ke keluarga pengantin laki-laki) pada adat perkawinan Sasak. Pembayun atau juru bicara dan sekaligus ketua rombongan (20 sampai 30 orang) dari keluarga mempelai laki-laki bertugas membawa harta gegawan atau bawaan yang akan diberikan kepada keluarga pengantin perempuan.

${ }^{2}$ Sorong serah secara harafiah artinya 'serah terima', yaitu sebuah acara adat dalam prosesi perkawinan suku Sasak dalam rangka menyerahkan sejumlah barang bawaan ke pihak pangantin perempuan berdasarkan kesepakatan yang sudah dibuat antara pihak keluarga pengantin laki-laki dan perempuan.
} 


\section{SURVEI PEMAKAIAN 'BASA SASAK ALUS' DI KALANGAN GENERASI MUDA SASAK DI LOMBOK}

\section{Data Pribadi}

Berilah tanda silang (x) pada pilihan jawaban (apakah a, b, c, d, atau e,) sesuai yang saudara inginkan. Jika tidak terdapat pilihan jawaban, berilah jawaban sendiri pada kolom yang telah disediakan.

1) Termasuk kelompok umur yang manakah saudara:
a) $11-15$ tahun
b) $16-20$ tahun
c) $21-25$ tahun
d) $26-30$ tahun
e) $31-35$ tahun

2) Apakah jenis kelamin saudara?
a) Pria
b) Wanita

3) Di manakah saudara tinggal dan apakah saudara dari keluarga Menak atau Biasa?

4) Dari keluarga manakah Ayah dan Ibu saudara ?
$>$ Ayah:
a) Keluarga biasa
b) Keluarga menak
$>$ Ibu :
a) Keluarga biasa
b) Keluarga menak

5) Apa pendidikan tertinggi orangtua saudara?

Sebutkan: a) Ayah

b) Ibu

6) Apa pendidikan saudara yang terakhir atau sekarang?
a) Saya tidak pernah sekolah
b) Siswa SD/Madrasah Ibtida'iyah
c) Siswa SMP/Mts
d) Siswa SMA/SMK/Aliyah
e) Mahasiswa/i
f) Tamat Perguruan Tinggi /Akademi.
g) Lainnya, sebutkan:

7) Jika saudara bekerja, apa pekerjaan saudara sekarang?

\section{Data Latar Kebahasaan}

1. Apakah saudara mengetahui bahwa dalam bahasa Sasak dikenal juga 'Basa Sasak Alus' dan 'Basa Sasak Jamak' atau 'Biasa'?
a. Ya
b. Tidak

2. Menurut saudara ada berapa sebenarnya tingkatan bahasa Sasak itu, dua, atau tiga?

a. Ada dua saja, yaitu Sasak Alus dan Sasak Jamak/Biase.

b. Ada tiga, yaitu Sasak Jamak (Aoq-ape), Sasak Alus (Tiang-inggih), dan Sasak Alus Kaji-meran.

Jika anda tahu sebutkan namanya:

3. Apakah di keluarga anda, orangtua anda pernah mengajarkan atau memperdengarkan kosa kata 'Base Alus' kepada anda?
a. (Hampir) selalu
b. Sering
c. Pernah
d. Tidak pernah 
4. Jika anda sudah berkeluarga dan mempunyai anak, apakah sauadara pernah mengajarkan Basa Alus (Tiang-Nggih) kepada putra-putri saudara?
a. (Hampir) selalu
b. Sering
c. Pernah
d. Tidak pernah

5. Apakah saudara pernah menggunakan bahasa Sasak Alus dengan : a). orangtua atau famili lainnya di rumah?
i. (Hampir) selalu
iii. Jarang
ii. Sering
iv. Tidak pernah

b). guru (atau pegawai tata usaha) di sekolah?
i. (Hampir) selalau
iii. Jarang
ii. Sering
iv. Tidak pernah

c) orang yang dituakan atau dihormati di kampung, di kantor, atau dimana saja memungkinkan?
i. (Hampir) selalu
iii. Jarang
ii. Sering
iv. Tidak pernah

6. Apakah di sekolah anda (di SMP/MTs atau SMA/MA/SMK) para siswa diajarkan 'Basa Sasak Alus'?
a. Ya
b. Tidak

7. Apa pendapat anda jika anda jarang atau tidak pernah menggunakan 'Basa Sasak Alus'?
a. Takut salah
b. Karena memang tidak bisa, keluarga saya tidak menggunakan ragam bahasa itu.
c. Kosa kata "Basa Alus' saya sangat sedikit
d. Karena jarang mendengar orang memakai Basa Alus
e. Lainnya:

8. Apakah saudara tahu apa bahasa Sasaknya 'Terima kasih'?
a. Ya, tahu. Sebutkan
b. Tidak tahu.

9. Apakah saudara pernah mengucapkan kata 'Terima kasih' dalam bahasa Sasak?
a. (Hampir) selalu
c. Jarang
b. Sering
d. Tidak pernah

10. Menurut saudara, kira-kira berapa banyak kosa kata halus Bahasa Sasak yang saudara ketahui?
a. Hanya dua saja, yaitu Tiang dan Nggih/Inggih.
b. Kurang dari sepuluh kata.
c. Kira-kira belasan kata lebih.
d. Banyak sekali

11. Apakah anda setuju bahwa 'Basa Sasak Alus' mengajarkan kepada kita tata krama atau sopan santun berbahasa (khususnya bahasa Sasak) dan karena itu perlu diajarkan?
a. sangat setuju
b. setuju
c. tidak setuju

\section{Pengetahuan dan Penguasaan Kosa Kata}

Petunjuk: Tuliskan Bahasa Sasak Jamak dari dari kata-kata Bahasa Sasak Alus berikut ini.
1. asme
2. bije
3. sanak
4. gading
5. pageran
6. gedeng/pegedengan :
7. penjarupan 

8. margi/lumbar
9. melinggih
10. matur
11. antos/ngantos
12. tunas/nunas
13. sermin
14. pirengan
15. wikan
16. rauh
17. ampure
18. silaq/dawek
19. lingsir
20. utawi
21. sarang
22. plungguh
23. mangkin
24. mindah
25. sampun

\section{Penggunaan Bahasa Sasak Halus}

\section{Petunjuk:}

Apa bahasa Sasak Alus dari kalimat-kalimat Bahasa Indonesia berikut ini.

1. Ada apa Pak?

2. Apakah saya jadi ikut pergi bersama bapak?

3. Amin: Apa katanya Bapak?

Adi: Saya tidak tahu!

4. Apakah Bapak sudah makan?

5. Ayah saya sudah datang.

6. Sudah ada tamu yang datang?

7. Mari, sini di berugak kita duduk.

8. Bapak sedang pergi ke mana?

9. Pak permisi numpang tanya. Dimana rumah Bapak Nasip?

10. Silakan makan dulu pak, sekarang sudah siang.

11. Apa yang bapak cari?

12. Apakah Bapak tahu pak Rustam sudah datang? 